Michał Kościółek

Jacek Strojny

Politechnika Rzeszowska

\title{
Zastosowanie smart specialisation przy wykorzystaniu benchmarkingu na przykładzie województwa podkarpackiego i małopolskiego
}

\author{
The application of smart specialisation using the method of benchmarking \\ on the example of the Podkarpacie and Malopolskie Voivodeships
}

\begin{abstract}
Streszczenie
Zróżnicowanie w rozwoju społeczno-gospodarczym poszczególnych regionów to jedno z największych wyzwań wszystkich gospodarek. Zbadanie wielkości tych różnic oraz wskazanie możliwości ich zmniejszenia to jedno z najtrudniejszych zadań każdej gospodarki. Metodą pozwalająca na wskazanie podmiotów, z których należy czerpać wzorce, jest benchmarking. Została ona opisana $\mathrm{w}$ artykule na przykładzie jednostek samorządu terytorialnego wraz z odwołaniem do inteligentnej specjalizacji, która jest określana w dokumentach europejskich jako jedna z możliwości przeciwdziałania fragmentaryzacji rynków.

Celem tekstu jest ocena konkurencyjnej pozycji województw podkarpackiego i małopolskiego pod kątem innowacji oraz badań i rozwoju. W artykule wybrano wskaźniki związane ze sferą badawczo-rozwojową oraz działalnością innowacyjną. Miały one na celu wskazanie potencjału tych działań i pokazanie trendów na przyszłość.

Analizy dokonano na przykładzie województw małopolskiego i podkarpackiego. Obszar ten charakteryzuje się odmiennością rozwojową, dlatego stanowi on ciekawy przykład do prowadzenia badań. Analiza wykazała, że w województwie małopolskim większe środki są przeznaczane na sferę badawczo-rozwojową oraz na działalność innowacyjną, co może przynieść korzyści w późniejszych okresach. Można do nich zaliczyć szybsze tempo rozwoju czy lepszą pozycję konkurencyjną jednostek samorządu na obszarze całego kraju.
\end{abstract}

\footnotetext{
Abstract

The variation in the socio-economic development of individual regions is one of the biggest challenges facing all economies. Examining the scope of these differences and identifying opportunities to reduce them is one of the key challenges of any economy. The method allowing for the identification of entities that should be used as an example, is the method of benchmarking. It has been described in the article on the example of local government units with reference to smart specialisation, which is described in European documents as one possibility to address market fragmentation.

The article selected indicators related to research and development and innovation activities. They had to identify the potential in this field, and show the trends for the future. The analysis was conducted on the example of the Malopolskie and Podkarpackie voivodeships. This area is characterised by differences in development. This is an interesting example for testing. The analysis showed that in the Malopolskie voivodeship more resources are allocated to research and development and innovation activities, which can bring benefits in future periods. These benefits may include faster development and the better competitive position of local self-government units in the entire country.
} 
Słowa kluczowe: benchmarking; jednostki samorządu terytorialnego; rozwój; region; zarządzanie Keywords: development; the region; benchmarking; management; local self-government units

\section{Wstęp}

Zróżnicowanie poziomu rozwoju społeczno-gospodarczego poszczególnych regionów jest jednym z największych wyzwań wszystkich gospodarek. Aby móc osiągać zadowalające wyniki zarówno w sferze społecznej, jak i gospodarczej, konieczna jest współpraca między biznesem (przedsiębiorstwami) a jednostkami samorządu terytorialnego. Współpraca obu podmiotów może się przyczynić do wspólnego koordynowania i realizowania działań zgodnych z polityką rozwoju regionalnego. Obecnie poszukiwane są nowe czynniki mogące zapewnić konwergencję regionalną (Chyrski, 2005).

Celem niniejszego artykułu jest ocena konkurencyjnej pozycji województw podkarpackiego i małopolskiego pod kątem innowacji oraz badań i rozwoju. Oceny tej dokonano przy pomocy wyselekcjonowanych wskaźników. Dzięki metodzie benchmarkingu można było wskazać podmiot wzorcowy.

Niniejszy tekst został podzielony na trzy części. W pierwszej przedstawiono istotę smart specialization w zarządzaniu jednostką samorządu terytorialnego. W drugiej pokazano metodę benchmarkingu jako narzędzia do analizy konkurencyjnej pozycji jednostek samorządu terytorialnego. W trzeciej, ostatniej części, dokonano oceny konkurencyjnej pozycji województwa podkarpackiego i małopolskiego w odniesieniu do innowacji oraz badań i rozwoju. Ocena ta odbywała się na przykładzie analizy porównawczej.

\section{Przegląd badań w podjętym temacie}

Badania w tematyce inteligentnej specjalizacji, smart specialisation, dotyczą głównie regionów zlokalizowanych na terenie Unii Europejskiej. Miłek (2012) w swoim artykule opisuje rolę smart specialisation bez przypisywania jej do konkretnych regionów. Omawia temat czysto teoretycznie - podobną formę swojego artykułu przyjął Janusz (2013). Jednak ten autor odnosi tematykę smart specialisation zarówno do Strategii Lizbońskiej, jak i Strategii Europa 2020, szukając różnic i podobieństw w podejściu do tego zagadnienia.

W odniesieniu do regionów problematykę tę można odnaleźć w dokumencie Inteligentna Specjalizacja Województwa Mazowieckiego, jednak przeprowadzona tam analiza jest czysto teoretyczna, nie wsparta wartościami liczbowymi odnoszącymi się chociażby do innych regionów. Tekst opublikowany w 44. numerze czasopisma „Panorama” opisuje poziom innowacyjności wszystkich regionów w Unii Europejskiej i na jego podstawie można wskazać różnice między danymi regionami.

Reasumując, w literaturze znajduje się wiele badań związanych z poziomem innowacyjności w odniesieniu do regionów z obszaru Unii Europejskiej. Są to zazwyczaj opracowania zbiorcze dla wszystkich krajów. Wiele prac jest też tylko teoretycznych. Zauważalny jest natomiast brak porównywania konkretnych dwóch lub więcej regionów przy wykorzystaniu metody benchmarkingu, celem określenia ich obecnej i przyszłej pozycji konkurencyjnej. Tematyka jest o tyle ważna, że na podstawie takich badań można opracować strategię działania na przyszłe lata.

\section{Istota smart specialization w zarządzaniu JST}

Pojęcie inteligentnej specjalizacji omówiono szczerzej w Polityce Spójności Unii Europejskiej po 2014 r., a dokładniej w Strategii Europa 2020. Strategia Europa 2020 to strategia opierająca się na działaniach na rzecz inteligentnego i zrównoważonego rozwoju, który ma sprzyjać włączeniu społecznemu. W jej myśl wpisuje się inteligentna specjalizacja, która w europejskich 
dokumentach opisywana jest jako „ścisłe powiązanie działalności badawczo-rozwojowej, rozwoju kapitału ludzkiego (kwalifikacji oraz umiejętności pracowników), specyfiki gospodarczej regionów lub państw” jak również „zidentyfikowanie i wybór dziedzin o największym potencjale, tych które mogą zapewnić przewagę konkurencyjną regionu (subregionu) na poziomie międzynarodowym i skoncentrowanie na nich wsparcia, w tym szczególnie w zakresie badań i rozwoju innowacji” (Komisja Europejska, 2010). Pojęcia te należy jednak rozszerzyć: inteligentna specjalizacja nie musi się odnosić do jednej konkretnej branży, może być to podejście międzysektorowe. Podobnie jest w przypadku nowych technologii - nie muszą one być przystosowane do działania we wszystkich dziedzinach, mogą być dostosowane do jednej wybranej dziedziny lub kilku - najczęściej kluczowych dla danego regionu. Jeśli chodzi o przewagę międzynarodową, to należy wspomnieć, że chodzi przede wszystkim o zdobycie tej przewagi na arenie krajowej, zostanie liderem w jakiejś konkretnej dziedzinie.

Odnosząc się do tego samego dokumentu, Komisja Europejska wyodrębniła kilka najważniejszych celów inteligentnej specjalizacji:

- przeciwdziałanie fragmentaryzacji i duplikacji badań naukowych w ramach Europejskiej Przestrzeni Badawczej,

- osiągnięcie masy krytycznej w kluczowych dla konkurencyjności Europy obszarach i sektorach,

- rozprzestrzenienie technologii ogólnego zastosowania, zwłaszcza przez wykorzystywanie ich w produktach i usługach,

- wzmocnienie lokalnych potencjałów w zakresie prowadzenia działalności B+R+I,

- wzmocnienie zaangażowania różnych interesariuszy w proces tworzenia strategii,

- programowanie i wdrażanie polityk w oparciu o dowody (Komisja Europejska, 2010).

Warto również wskazać podmioty, które są badane podczas stosowania inteligentnej specjalizacji:

- przedsiębiorstwa, sieci przedsiębiorców (klastry, zrzeszenia przedsiębiorców),

- instytucje otoczenia biznesu (sieci innowacji, sieci przedsiębiorczość), jednostki naukowe i badawcze,

- ośrodki finansowania innowacji,

- instytucje rynku pracy,

- społeczeństwo regionu kształtujące kapitał społeczny regionu,

- osoby przebywające w regionie,

- podmioty samorządowe.

Cele zapisane w Strategii Europa 2020 odnosiły się do wszystkich krajów członkowskich Unii Europejskiej. Kolejnym etapem jej tworzenia było wyodrębnienie Krajowych Inteligentnych Specjalizacji oraz stworzenie Strategii Rozwoju dla poszczególnych województw do 2020 r. W Strategiach Rozwoju każde województwo określa cele, dziedziny działań strategicznych oraz priorytety tematyczne. Ma to na celu wyodrębnienie najważniejszych a zarazem kluczowych obszarów w danym województwie, obszarów, na których będzie się opierać strategia pozwalająca osiągnąc przewagę konkurencyjną. Równie ważne dla tworzenia strategii jest wskazanie kierunków działania w poszczególnych obszarach, sposobu i metod służących realizacji zamierzonych celów oraz narzędzi do pomiaru wyników. Przy tworzeniu i realizacji strategii ważna jest współpraca między zainteresowanymi podmiotami (Samorząd Województwa Podkarpackiego, 2013).

Inteligentna specjalizacja jest równie ważna w odniesieniu do jednostek samorządu terytorialnego. Każda z nich powinna wyznaczyć obszary, w których czuje się najmocniej albo uważa, że ma w niej największe niewykorzystane zasoby. Następnym krokiem powinno być skupienie 
swoich działań na tych konkretnych obszarach. Dzięki temu można osiągnąć lepsze wyniki oraz przewagi konkurencyjne w jednym lub kilku obszarach. Jednostki samorządu terytorialnego, podobnie jak regiony, konkurują ze sobą pod wieloma względami, jednak jest to pozytywna konkurencja, pozwalająca na uzyskanie dodatnich rezultatów.

\section{Benchmarking jako narzędzie do analizy pozycji konkurencyjnej JST}

Benchmarking został szeroko opisany zarówno w literaturze polskiej, jak i zagranicznej. W publikacjach tych pojawiło się wiele definicji tego pojęcia. Według Martyniaka, benchmarking polega na porównaniu cech organizacji z konkurentami lub firmami wiodącymi w danej branży, oraz kopiowaniu sprawdzonych wzorów (Martyniak, 1996), natomiast jedną z najpopularniejszych definicji zaproponował Camp (1989), który określał benchmarking jako ,poszukiwanie najefektywniejszych metod dla danej działalności, pozwalających osiągnąć przewagę konkurencyjną”. Z obu definicje można spróbować stworzyć jedną, w której benchmarking byłby procesem systematycznego porównywania danego podmiotu z jej najbliższymi i dalszymi konkurentami, jak również polegałby na porównywaniu obszarów czy działów wewnątrz jednostki, aby móc w jak najefektywniej określić obecny stan i szukać rozwiązań, które pomogłyby w przyszłości osiągnąć jeszcze lepsze wyniki.

Aby skutecznie użyć narzędzia, jakim jest benchmarking, należy się stosować do kolejnych etapów jego tworzenia (tab. 1).

Tab. 1. Etapy benchmarkingu

\begin{tabular}{|c|c|}
\hline Etap & Kroki \\
\hline planowanie & $\begin{array}{l}\text { - identyfikacja przedmiotu badań } \\
\text { - identyfikacja przedsiębiorstw do porównań } \\
\text { - wybór metody zbierania danych }\end{array}$ \\
\hline analiza & $\begin{array}{l}\text { - przeprowadzenie badania } \\
\text { • ustalenie odchyleń w zakresie efektywności } \\
\text { • określenie poziomów przyszłych wyników }\end{array}$ \\
\hline integracja & $\begin{array}{l}\text { - komunikowanie wyników benchmarkingu } \\
\text { - ustalenie celów funkcjonalnych }\end{array}$ \\
\hline wdrożenie & $\begin{array}{l}\text { - opracowanie planu wdrożenie } \\
\text { - uruchomienie działań wdrożeniowych } \\
\text { - kontrola wdrożenia } \\
\text { - określenie nowych benchmarków }\end{array}$ \\
\hline
\end{tabular}

Źródło: Martyniak, 1996.

Pierwszy etap to planowanie. Jest ono równie ważne, jak kolejny krok, czyli analiza. Jeśli na początku badań wybierzemy złe podmioty czy obszary do przeprowadzenia późniejszej analizy, to może się okazać, że sytuacja jest dużo lepsza niż w rzeczywistości. Kolejny etap to analiza właściwa w odniesieniu do badanych wielkości oraz wskaźników. Porównuje się je w celu ustalenia obecnych odchyleń oraz prognozowania przyszłych, oczekiwanych wyników. Trzecim etapem jest integracja. Następuje ona po przeanalizowaniu wyników uzyskanych na etapie analizy i jej efektem jest określenie celów funkcjonalnych - ważne, aby cele te były realne i możliwe do zrealizowania. Ostatni etap to opracowanie planu wdrożenia zmian, które mają na celu poprawę funkcjonowania danego podmiotu oraz jego późniejsze kontrolowanie. Ostatnie zadanie na tym etapie polega na wskazaniu nowych benchmarków. Jest to niezmiernie ważne, żeby dany podmiot mógł się nieustannie rozwijać. 
Dzięki benchmarkingowi jednostki samorządu terytorialnego mogą poprawiać swoją pozycję konkurencyjną. W niniejszym artykule jest ona rozumiana jako atrakcyjność danego obszaru względem podmiotów, które w swobodny sposób mogą zmieniać swoją lokalizację, np. turystów, mieszkańców, firm. Porównywanie się z innymi jednostkami - sąsiadującymi z nimi albo znajdującymi się w innym rejonie kraju - lub porównywanie konkretnych obszarów działań w ramach jednej jednostki stwarza szerokie możliwości oceny sytuacji danego terytorium. Jest to niezmiernie ważne, ponieważ dzięki benchmarkingowi jednostka samorządu może określić swoją pozycję na rynku lub w branży, a przechodząc pozytywnie przez kolejne etapy benchmarkingu, poprawiać tę pozycję.

\section{Ocena pozycji konkurencyjnej województw podkarpackiego i małopolskiego w innowacje i $B+R$ jako przykład wykorzystania analizy porównawczej}

Oceny pozycji konkurencyjnej w obszarze innowacji i $\mathrm{B}+\mathrm{R}$ dokonano na podstawie analizy kilku wyselekcjonowanych wskaźników. Zostały one dobrane pod kątem oceny działalności w tych obszarach w odniesieniu do dwóch województw: podkarpackiego i małopolskiego. Wybrane wskaźniki:

- nakłady inwestycyjne ogółem na 1 mieszkańca,

- nakłady inwestycyjne w sektorze publicznym na 1 mieszkańca,

- nakłady inwestycyjne w sektorze prywatnym na 1 mieszkańca,

- nakłady na działalność innowacyjną w przedsiębiorstwach z sektora usług,

- nakłady na działalność innowacyjną w przedsiębiorstwach przemysłowych,

- nakłady na działalność badawczo-rozwojową $(\mathrm{B}+\mathrm{R}) \mathrm{w}$ przedsiębiorstwach z sektora usług,

- nakłady na działalność badawczo-rozwojową (B+R) w przedsiębiorstwach przemysłowych,

- nakłady wewnętrzne na działalność badawczo-rozwojową (B+R) na 1 mieszkańca,

- nakłady wewnętrzne na działalność badawczo-rozwojową na 1 zatrudnionego w B+R.

Informacje dotyczące tych wskaźników w odniesieniu do dwóch wyżej wspomnianych województw zostały pozyskane z Głównego Urzędu Statystycznego. Analizę wzbogacono o następujące dane dotyczące całego kraju:

- inteligentna specjalizacja województw,

- stopa bezrobocia,

- wydatki na 1 mieszkańca.

W kolejnych okresach nakłady inwestycyjne w przeliczeniu na 1 mieszkańca rosły zarówno w województwie podkarpackim, jak i małopolskim (tab. 2). Od roku 2002 do 2009 zauważyć można przewagę województwa małopolskiego nad podkarpackim, jednak od 2010 sytuacja ta zmieniła się na korzyść województwa podkarpackiego.

Tab. 2. Nakłady inwestycyjne ogółem na 1 mieszkańca (w zł)

\begin{tabular}{|c|c|c|c|c|c|c|c|c|c|c|c|}
\hline Województwo & $\mathbf{2 0 0 2}$ & $\mathbf{2 0 0 3}$ & $\mathbf{2 0 0 4}$ & $\mathbf{2 0 0 5}$ & $\mathbf{2 0 0 6}$ & $\mathbf{2 0 0 7}$ & $\mathbf{2 0 0 8}$ & $\mathbf{2 0 0 9}$ & $\mathbf{2 0 1 0}$ & $\mathbf{2 0 1 1}$ & $\mathbf{2 0 1 2}$ \\
\hline małopolskie & 2546 & 2844 & 2821 & 3082 & 3967 & 4637 & 4905 & 4526 & 4811 & 5431 & 5468 \\
\hline podkarpackie & 1948 & 2168 & 2345 & 2440 & 2817 & 3351 & 3759 & 4064 & 4837 & 6306 & 5902 \\
\hline
\end{tabular}

Źródło: opracowanie własne na podstawie danych GUS.

Wskaźnik nakładów inwestycyjnych w sektorze publicznym na 1 mieszkańca (tab. 3) kształtuje się podobnie jak wskaźnik nakładów inwestycyjnych ogółem w przeliczeniu na 1 mieszkańca. 
Należy jednak zauważyć, że w 2011 r. województwo podkarpackie nie tylko nadrobiło stratę nad województwem małopolskim, ale osiągnęło znaczącą przewagę (wynoszącą ponad 50\%).

Tab. 3. Nakłady inwestycyjne w sektorze publicznym na 1 mieszkańca (w zł)

\begin{tabular}{|c|c|c|c|c|c|c|c|c|c|c|c|}
\hline Województwo & $\mathbf{2 0 0 3}$ & $\mathbf{2 0 0 4}$ & $\mathbf{2 0 0 5}$ & $\mathbf{2 0 0 6}$ & $\mathbf{2 0 0 7}$ & $\mathbf{2 0 0 8}$ & $\mathbf{2 0 0 2}$ & $\mathbf{2 0 0 9}$ & $\mathbf{2 0 1 0}$ & $\mathbf{2 0 1 1}$ & $\mathbf{2 0 1 2}$ \\
\hline małopolskie & 915 & 924 & 1017 & 1351 & 1529 & 1733 & 877 & 1808 & 2003 & 2235 & 2429 \\
\hline podkarpackie & 731 & 785 & 882 & 1081 & 1040 & 1213 & 716 & 1754 & 2598 & 3575 & 3160 \\
\hline
\end{tabular}

Źródło: opracowanie własne na podstawie danych GUS.

W województwie małopolskim nakłady inwestycyjne w sektorze prywatnym na 1 mieszkańca (tab. 4) rosną z roku na rok. Jedynie w latach 2009 i 2012 widzimy spadek tego wskaźnika w stosunku do okresu poprzedzającego. Podobnie sytuacja wygląda w województwie podkarpackim - różni ją to, że spadek wskaźnika jest widoczny w latach 2006, 2010 i 2011. Różnica między tymi dwoma województwami jest na podobnym poziomie przez cały badany okres.

Tab. 4. Nakłady inwestycyjne w sektorze prywatnym na 1 mieszkańca (w zł)

\begin{tabular}{|c|c|c|c|c|c|c|c|c|c|c|c|}
\hline Województwo & $\mathbf{2 0 0 2}$ & $\mathbf{2 0 0 3}$ & $\mathbf{2 0 0 4}$ & $\mathbf{2 0 0 5}$ & $\mathbf{2 0 0 6}$ & $\mathbf{2 0 0 7}$ & $\mathbf{2 0 0 8}$ & $\mathbf{2 0 0 9}$ & $\mathbf{2 0 1 0}$ & $\mathbf{2 0 1 1}$ & $\mathbf{2 0 1 2}$ \\
\hline małopolskie & 1669 & 1929 & 1897 & 2065 & 2616 & 3108 & 3172 & 2718 & 2808 & 3196 & 3039 \\
\hline podkarpackie & 1232 & 1437 & 1560 & 1558 & 1736 & 2311 & 2546 & 2310 & 2239 & 2731 & 2742 \\
\hline
\end{tabular}

Źródło: opracowanie własne na podstawie danych GUS.

Kolejnym badanym wskaźnikiem są nakłady na działalność innowacyjną w przedsiębiorstwach z sektora usług (tab. 5). Nie wszystkie dane dotyczące analizowanych przedziałów czasowych można pozyskać z Głównego Urzędu Statystycznego, jednak z dostępnych danych można wywnioskować, że przewaga województwa małopolskiego nad podkarpackim jest niepodważalna we wszystkich latach. Największa przewaga widoczna jest w 2009 i 2012 r. W 2009 w województwie małopolskim badane nakłady były ponad dziewięciokrotnie wyższe niż w województwie podkarpackim.

Tab. 5. Nakłady na działalność innowacyjną w przedsiębiorstwach z sektora usług (w tys. zł)

\begin{tabular}{|l|c|c|c|c|c|c|c|c|}
\hline Województwo & $\mathbf{2 0 0 6}$ & $\mathbf{2 0 0 7}$ & $\mathbf{2 0 0 8}$ & $\mathbf{2 0 0 9}$ & $\mathbf{2 0 1 0}$ & $\mathbf{2 0 1 1}$ & $\mathbf{2 0 1 2}$ & $\mathbf{2 0 1 3}$ \\
\hline małopolskie & 255841 & - & 244575 & 384249 & 273106 & 231459 & 639917 & 431599 \\
\hline podkarpackie & 91615 & - & 107464 & 40344 & 75733 & 193788 & 260073 & 0 \\
\hline
\end{tabular}

Źródło: opracowanie własne na podstawie danych GUS.

W przypadku nakładów na działalność innowacyjną w przedsiębiorstwach przemysłowych (tab. 6) również widoczna jest znaczna przewaga województwa małopolskiego nad województwem podkarpackim. W 2011 r. oba województwa przeznaczyły podobne środki na nakłady inwestycyjne, w kolejnych dwóch latach województwo podkarpackie odbiegało od województwa małopolskiego. 
Tab. 6. Nakłady na działalność innowacyjną w przedsiębiorstwach przemysłowych (w tys. zł)

\begin{tabular}{|c|c|c|c|c|c|c|c|c|c|}
\hline Województwo & $\mathbf{2 0 0 5}$ & $\mathbf{2 0 0 6}$ & $\mathbf{2 0 0 7}$ & $\mathbf{2 0 0 8}$ & $\mathbf{2 0 0 9}$ & $\mathbf{2 0 1 0}$ & $\mathbf{2 0 1 1}$ & $\mathbf{2 0 1 2}$ & $\mathbf{2 0 1 3}$ \\
\hline małopolskie & 866256 & 1317973 & 1183315 & 1294657 & 1085726 & 1083536 & 1205739 & 1360768 & 1807271 \\
\hline podkarpackie & 670984 & 922582 & 895714 & 978447 & 1000322 & 937877 & 1174258 & 1182844 & 1149499 \\
\hline
\end{tabular}

Źródło: opracowanie własne na podstawie danych GUS.

Tabela 7 przedstawia nakłady na działalność badawczo-rozwojową w przedsiębiorstwach z sektora usług. Nie dla wszystkich okresów można pozyskać dane na ten temat z Głównego Urzędu Statystycznego. Jednak ze zgromadzonych informacji można wywnioskować, że nakłady na ten obszar w województwie małopolskim rosły w kolejnych latach, a ich spadek nastąpił dopiero w 2013 r. Rok 2012 był rokiem rekordowym, wtedy przeznaczono na działalność B+R aż 477 mln złotych. Województwo podkarpackie notowało w kolejnych latach: 2008, 2009 i 2010 spadek nakładów.

Tab. 7. Nakłady na działalność badawczo-rozwojową w przedsiębiorstwach z sektora usług (w tys. zł)

\begin{tabular}{|c|c|c|c|c|c|c|c|c|}
\hline Województwo & $\mathbf{2 0 0 6}$ & $\mathbf{2 0 0 7}$ & $\mathbf{2 0 0 8}$ & $\mathbf{2 0 0 9}$ & $\mathbf{2 0 1 0}$ & $\mathbf{2 0 1 1}$ & $\mathbf{2 0 1 2}$ & $\mathbf{2 0 1 3}$ \\
\hline małopolskie & 16362 & - & 26120 & 93720 & 97175 & 95039 & 477694 & 214181 \\
\hline podkarpackie & 11428 & - & 24798 & 18795 & 6075 & 0 & 0 & 0 \\
\hline
\end{tabular}

Źródło: opracowanie własne na podstawie danych GUS.

Nakłady na działalność badawczo-rozwojową w przedsiębiorstwach przemysłowych (tab. 8) w przeciwieństwie do nakładów na działalność $\mathrm{B}+\mathrm{R}$ w przedsiębiorstwach z sektora usług rosną w województwie podkarpackim z roku na rok, jedyny spadek był w 2007 r. Wskaźnik ten osiągnął maksymalną wartość w 2013 r. i wyniósł 466 mln złotych. W województwie podkarpackim nakłady na działalność B $+\mathrm{R}$ w przedsiębiorstwach przemysłowych były wyższe od województwa małopolskiego jedynie w trzech ostatnich badanych latach: 2011, 2012 i 2013.

Tab. 8. Nakłady na działalność badawczo-rozwojową w przedsiębiorstwach przemysłowych (w tys. zł)

\begin{tabular}{|c|c|c|c|c|c|c|c|c|c|}
\hline Województwo & $\mathbf{2 0 0 5}$ & $\mathbf{2 0 0 6}$ & $\mathbf{2 0 0 7}$ & $\mathbf{2 0 0 8}$ & $\mathbf{2 0 0 9}$ & $\mathbf{2 0 1 0}$ & $\mathbf{2 0 1 1}$ & $\mathbf{2 0 1 2}$ & $\mathbf{2 0 1 3}$ \\
\hline małopolskie & 202770 & 277406 & 182983 & 155000 & 188638 & 221368 & 268401 & 288994 & 458278 \\
\hline podkarpackie & 99403 & 119820 & 109321 & 120200 & 154754 & 204982 & 277449 & 416240 & 466001 \\
\hline
\end{tabular}

Źródło: opracowanie własne na podstawie danych GUS.

Nakłady na działalność B+R w przeliczeniu na 1 mieszkańca (tab. 9) w latach 2002-2005 w województwie podkarpackim kształtowały się na poziomie 50 zł, natomiast w województwie małopolskim - między 150 a 200 zł. W kolejnych latach w obu województwach wskaźnik ten rósł. Największy wzrost zanotowano w województwie podkarpackim między 2009 a 2010 r. - był to skok ponad dwukrotny. 
Tab. 9. Nakłady na działalność badawczo-rozwojową na 1 mieszkańca (w zł)

\begin{tabular}{|c|c|c|c|c|c|c|c|c|c|c|c|}
\hline Województwo & $\mathbf{2 0 0 2}$ & $\mathbf{2 0 0 3}$ & $\mathbf{2 0 0 4}$ & $\mathbf{2 0 0 5}$ & $\mathbf{2 0 0 6}$ & $\mathbf{2 0 0 7}$ & $\mathbf{2 0 0 8}$ & $\mathbf{2 0 0 9}$ & $\mathbf{2 0 1 0}$ & $\mathbf{2 0 1 1}$ & $\mathbf{2 0 1 2}$ \\
\hline małopolskie & 154 & 160 & 198 & 224 & 222,1 & 243,9 & 272,8 & 280,2 & 327,7 & 362,3 & 488,9 \\
\hline podkarpackie & 57 & 55 & 50 & 53 & 75 & 74,6 & 84,6 & 90 & 238,9 & 254,8 & 298 \\
\hline
\end{tabular}

Źródło: opracowanie własne na podstawie danych GUS.

Sytuacja w odniesieniu do nakładów wewnętrznych na działalność badawczo-rozwojową na 1 zatrudnionego w B $+\mathrm{R}$ (tab. 10) odbiega od tej w przeliczeniu na 1 mieszkańca (tab. 9). W pierwszych dwóch badanych okresach: 2002 i 2003 r. oraz w latach 2010 i 2011 w województwie podkarpackim zanotowano wyższe wydatki na sferę $\mathrm{B}+\mathrm{R}$ w przeliczeniu na 1 zatrudnionego. Najwyższe wartości tego wskaźnika zanotowano w województwie małopolskim i podkarpackim w 2013 r.: wynosiły one odpowiednio 93,5 zł i 90,4 zł.

Tab. 10. Nakłady wewnętrzne na działalność badawczo-rozwojową na 1 zatrudnionego w $B+R$

\begin{tabular}{|c|c|c|c|c|c|c|c|c|c|c|c|}
\hline Województwo & $\mathbf{2 0 0 2}$ & $\mathbf{2 0 0 3}$ & $\mathbf{2 0 0 4}$ & $\mathbf{2 0 0 5}$ & $\mathbf{2 0 0 6}$ & $\mathbf{2 0 0 7}$ & $\mathbf{2 0 0 8}$ & $\mathbf{2 0 0 9}$ & $\mathbf{2 0 1 0}$ & $\mathbf{2 0 1 1}$ & $\mathbf{2 0 1 2}$ \\
\hline malopolskie & 28,8 & 30,8 & 38 & 47,1 & 54,2 & 57,9 & 66,3 & 66,4 & 74,9 & 79,1 & 93,5 \\
\hline podkarpackie & 40,4 & 35,1 & 35 & 35,7 & 50,5 & 50,2 & 52,8 & 53,3 & 84,1 & 81,9 & 90,4 \\
\hline
\end{tabular}

Źródło: opracowanie własne na podstawie danych GUS.

Inteligentna specjalizacja wybranych województw przedstawia, w czym specjalizuje się każde z nich. Opracowanie to zostało stworzone na podstawie strategii rozwoju województw i regionalnych strategii innowacji, a także dokumentów odnoszących się do inteligentnych specjalizacji poszczególnych regionów.

Tabela 11 przedstawia obszary, w których województwa małopolskie i podkarpackie się specjalizują. Można dostrzec tylko jeden punkt wspólny w zakresie specjalizacji. Jest to obszar ICT/multimedia. I tak, województwo małopolskie specjalizuje się w biogospodarce, energetyce oraz chemii, natomiast województwo podkarpackie - w wysokiej jakości życia oraz lotnictwie i kosmonautyce. Ten drugi obszar jest o tyle ważny, że żadne inne województwo nie zajmuje się nim na tak szeroką skalę, jak województwo podkarpackie. Jest to niewątpliwe szansa na osiągnięcie przewagi konkurencyjnej w Polsce oraz na zdobycie światowych rynków.

Rycina 1 przedstawia mapę z obrazem stopy bezrobocia w Polsce. Na jego podstawie można wywnioskować, że w województwie podkarpackim mamy wyższe bezrobocie niż w małopolskim. Analiza w ujęciu podregionalnym pokazuje wysoką wartość stopy bezrobocia w podregionie przemyskim, natomiast podregion miasto Kraków jest w wyjątkowo dobrej sytuacji.

Rycina 2 pokazuje średnie wydatki gospodarstw domowych w przeliczeniu na 1 mieszkańca w 2013 r. Skupiając się na sytuacji tylko w dwóch województwach: podkarpackim i małopolskim, można stwierdzić, że w małopolskim wydatki te są zdecydowanie wyższe. Jest to sytuacja o tyle dobra, że wydatki pobudzają gospodarkę i mogą przynieść późniejsze korzyści w postaci przeznaczanych przez przedsiębiorstwa środków na innowacje lub $B+R$, jak również większej ilości środków inwestowanych z kas samorządowych. 
Tab. 11. Inteligentna specjalizacja wybranych województw

\begin{tabular}{|c|c|c|c|c|c|c|c|c|c|c|c|c|c|c|c|c|}
\hline Województwo & 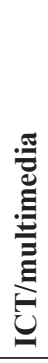 & 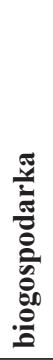 & 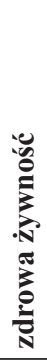 & 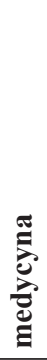 & 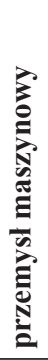 & $\begin{array}{l}\frac{\pi}{2} \\
\frac{\pi}{0} \\
\frac{50}{0} \\
\overline{0} \\
\overline{0}\end{array}$ & 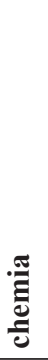 & 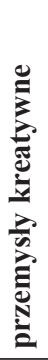 & 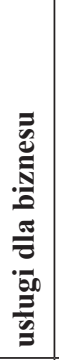 & $\begin{array}{l}0 \\
.0 \\
.0 \\
0 \\
0 \\
0 \\
0 \\
0 \\
0\end{array}$ & 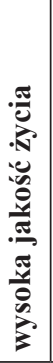 & 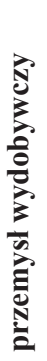 & 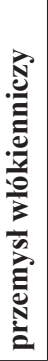 & 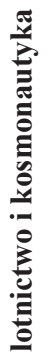 & 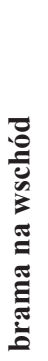 & 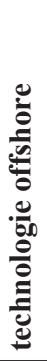 \\
\hline dolnośląskie & $\mathrm{X}$ & $\mathrm{X}$ & $X$ & $\mathrm{X}$ & $\mathrm{X}$ & & $\mathrm{X}$ & & & & & $\mathrm{X}$ & & & & \\
\hline kujawsko-pomorskie & $\mathrm{X}$ & $\mathrm{X}$ & $\mathrm{X}$ & $\mathrm{X}$ & $\mathrm{X}$ & & & $\mathrm{X}$ & & & & & & & & \\
\hline lubelskie & $\mathrm{X}$ & $\mathrm{X}$ & & $\mathrm{X}$ & & $\mathrm{X}$ & & & & & & & & & & \\
\hline małopolskie & $\mathrm{X}$ & $\mathrm{X}$ & & & & $\mathrm{X}$ & $\mathrm{X}$ & & & & & & & & & \\
\hline mazowieckie & $\mathrm{X}$ & & $\mathrm{X}$ & & & & & & $\mathrm{X}$ & & $\mathrm{X}$ & & & & & \\
\hline opolskie & & & $\mathrm{X}$ & & $\mathrm{X}$ & $\mathrm{X}$ & $\mathrm{X}$ & & & $\mathrm{X}$ & & & & & & \\
\hline podkarpackie & $\mathrm{X}$ & & & & & & & & & & $\mathrm{X}$ & & & $X$ & & \\
\hline podlaskie & & $\mathrm{X}$ & & & & & & & & & & & & & $X$ & \\
\hline pomorskie & $\mathrm{X}$ & $\mathrm{X}$ & & $\mathrm{X}$ & & $\mathrm{X}$ & & $\mathrm{X}$ & $\mathrm{X}$ & & & & & & & $\mathrm{X}$ \\
\hline śląskie & $\mathrm{X}$ & & & $X$ & & $\mathrm{X}$ & & & & & & & & & & \\
\hline świętokrzyskie & & & $\mathrm{X}$ & $\mathrm{X}$ & $\mathrm{X}$ & & & & & $\mathrm{X}$ & & & & & & \\
\hline
\end{tabular}

Źródło: opracowanie własne na podstawie strategii rozwoju poszczególnych województw.

Ryc. 1. Stopa bezrobocia rejestrowanego w Polsce w 2013 r. (w \%)

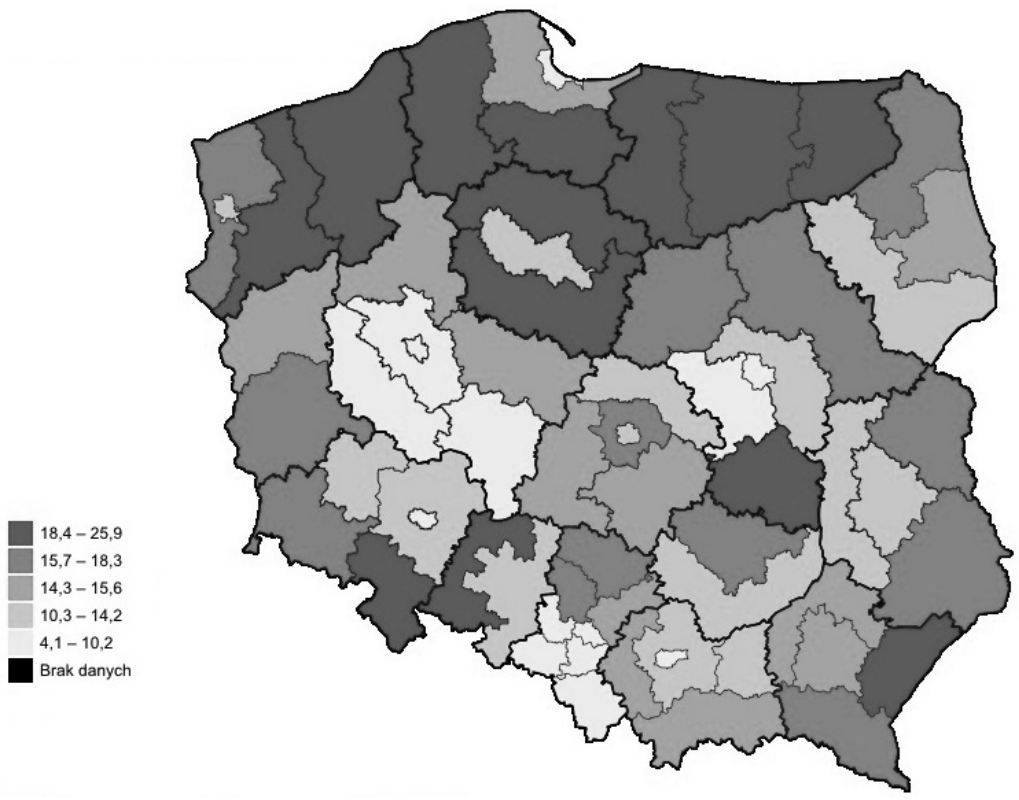

Źródło: opracowanie własne na podstawie danych systemu Strateg na dzień 21.10.2014. 
Ryc. 2. Wydatki gospodarstw domowych w przeliczeniu na 1 mieszkańca w 2013 r. (w zł)

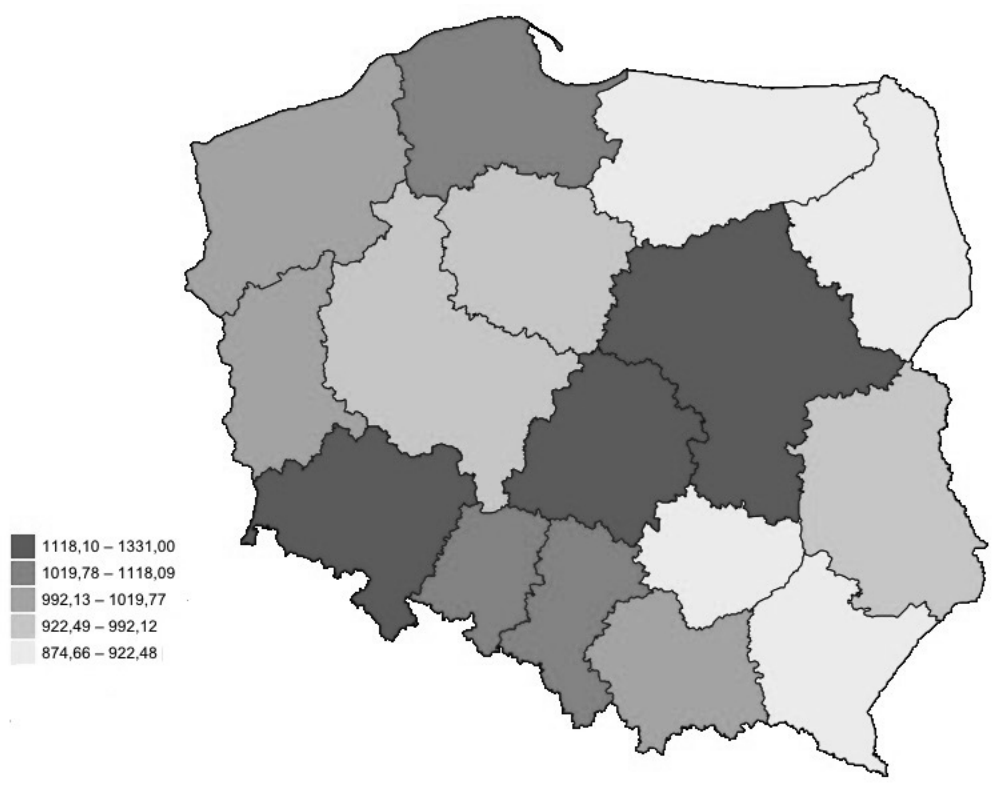

Źródło: opracowanie własne na podstawie danych systemu Strateg na dzień 21.10.2014.

\section{Podsumowanie}

Przeprowadzona analiza porównawcza w obszarze innowacji i $\mathrm{B}+\mathrm{R}$, w odniesieniu do województw podkarpackiego i małopolskiego, wykazuje lepszą sytuację w województwie małopolskim. Świadczą o tym zarówno wskaźniki bezpośrednio odnoszące się do nakładów przeznaczanych na te obszary, jak i dodatkowe analizy. W przypadku stopy bezrobocia województwo małopolskie może się pochwalić niższym wskaźnikiem. Jeśli spojrzymy na wydatki, to tutaj województwo małopolskie również wypada lepiej. Ostatni wskaźnik jest trudny do jednoznacznej oceny, ponieważ zbyt duża liczba inteligentnych specjalizacji w regionie może prowadzić do ich zacierania - jednak w przypadku tych dwóch województw mamy do czynienia z 3-4 specjalizacjami.

Do słabych stron województwa podkarpackiego należy zaliczyć zbyt niski poziom współpracy między przedsiębiorstwami a nauką, przejawiający się małą liczbą wspólnych projektów o charakterze innowacyjnym (stąd tak niskie nakłady na tę sferę) oraz niską aktywność w sferze badawczo-rozwojowej. Natomiast niewątpliwą szansą jest dla tego województwa posiadanie unikatowej w skali kraju specjalizacji lotnictwo i kosmonautyka.

Ograniczeniami badawczymi w tym obszarze był brak danych na poziomie powiatów czy gmin, aby móc wyodrębnić poszczególne jednostki terytorialne w obrębie województw, które charakteryzują się największą i najmniejszą wielkością analizowanych wskaźników. Jednym z możliwych dalszych kierunków badań w tym zakresie jest poszerzenie analizy o kolejne obszary badawcze. 


\section{Literatura \\ References}

Camp, R.C. (1989). Benchmarking: the Search for Industry Best Practices the Lead to Superior Performance. ASQC Quality Press.

Churski, P. (2005). Czynniki rozwoju regionalnego w świetle koncepcji teoretycznych. Zeszyty Naukowe Wyższej Szkoły Humanistyczno-Ekonomicznej we Włocławku. Nauki ekonomiczne. Gospodarka regionu na Jednolitym Rynku Europejskim. Wybrane zagadnienia, XIX, 3,

Fuley, T.R. (1987). Benchmarking: The Key to Developing Competitive Advantage In Mature Markets. Planning Review.

Gaczek, W., Matusiak, M. (2011). Innowacyjność gospodarek województw Polski Wschodniej-ocena, znaczenie, perspektywy.

Janusz, A. (2012). Inteligentna specjalizacja jako instrument wspierania rozwoju inicjatyw klastrowych. Łódź: Polskie Towarzystwo Ekonomiczne.

Komisja Europejska. (2010). Unia Innowacji. Bruksela.

Komisja Europejska. (2010). Strategia EUROPA 2020. Bruksela.

Komisja Europejska. (2012). Inteligentna specjalizacja - czynnik stymulujący przyszły rozwój gospodarczy Europy. Panorama, 44.

Martyniak, Z. (1996). Metody organizowania procesów pracy. Warszawa: PWE.

Miłek, D. (2013). Specjalizacje regionalne a Strategia Europa 2020.

Regionalna Strategia Innowacji dla Województwa Mazowieckiego. (2013). Inteligentna specjalizacja Województwa Mazowieckiego. Warszawa.

Samorząd Województwa Podkarpackiego. (2013). Strategia Rozwoju Województwa Podkarpackiego. Rzeszów.

Michał Kościółek, mgr. Studia wyższe ukończył w 2012 r. na Wydziale Ekonomii i Stosunków Międzynarodowych Uniwersytetu Ekonomicznego w Krakowie. Działalność naukową i dydaktyczną rozpoczął w 2013 r. na Politechnice Rzeszowskiej jako asystent w Katedrze Ekonomii, kierowanej przez dr hab. Stanisława Gędka, prof. PRz. Główne zainteresowania badawcze autora to przede wszystkim makroekonomia, funkcjonowanie rynku pracy oraz analiza rynków lokalnych i regionalnych.

Michal Kościółek, graduated from the Faculty of Economics and International Relations Higher education in 2012 at the Rzeszow University of Technology as an assistant in the Department of Economics, led by Professor Stanisław Gędek. The main research interests of the author is primarily macroeconomics, labor market functioning and analysis of local and regional markets.

Adres/Address: Politechnika Rzeszowska

al. Powstańców Warszawy 12

35-959 Rzeszów, Polska

e-mail: mkos@prz.edu.pl

Jacek Strojny, ekonomista, doktor nauk ekonomicznych w zakresie nauk o zarządzaniu, adiunkt w Katedrze Ekonomii Wydziału Zarządzania Politechniki Rzeszowskiej, Pełnomocnik dziekana ds. projektów rozwojowych i komercjalizacji badań. Specjalizuje się $\mathrm{w}$ problematyce implementacji metod i technik zarządzania w przedsiębiorstwach i jednostkach administracji publicznej, zarówno na poziomie zarządzania strategicznego, jak i operacyjnego. Jest autorem kilkudziesięciu publikacji dotyczących przedsiębiorczości i innowacji, rozwoju regionalnego i lokalnego oraz zarządzania 
projektami. Koordynował projekty wdrożenia innowacyjnych systemów zarządzania w kilkudziesięciu przedsiębiorstwach i samorządach. Jest także autorem strategii rozwoju lokalnego na poziomie gminnym i powiatowym.

Jacek Strojny, economist, PhD, Assistant Professor in the Department of Economics, Faculty of Management, Rzeszow University of Technology, The Deans Plenipotentiary for Development and Commercialization. He specializes in methods and techniques implementation in companies and public administration institutions on the strategic and operational level. The author of several dozen publications related to entrepreneurship, innovations, local and regional development and project management as well. He was a coordinator of many innovative implementation projects in companies and public institutions. He is the author of strategic documents prepared on the municipality and district level.

Adres/Address: Politechnika Rzeszowska

al. Powstańców Warszawy 12

35-959 Rzeszów, Polska

e-mail: jstrojny@prz.edu.pl 